UDK 811.11 .26

DOI 10.22363/2312-8011-2017-14-1-9-17

\title{
DISCURSIVE STRATEGY OF SCIENTIFIC REPORT AND ITS IMPLEMENTATION
}

\author{
L.V. Ekshembeeva \\ Kazakh National University of Al-Farabi \\ 050040, 79 Al-Farabi Prospect, Almaty, Kazakhstan
}

M.Sh. Musataeva

Abay Kazakh National Pedagogical University

050010, 13 Dostyk Prospect, Almaty, Kazakhstan

This article provides rationale for making strategic changes to the content of the scientific report. The necessity to put in the discourse of the scientific report two formations of strategic preferences at once is justified: on the one hand, the description of the scientific results as a product of conceptualization of scientific experience, and on the other hand, - alignment of marketing strategies as a tool for its commercialization.

The paper shows the basic tool conceptualization of scientific experience when describing the results of the study - The system of verb concepts in type of event. The semantic volume of verb concept allows to describe the content of the event, which is in mind represented by propositional structure of scenario. The results of the semantic analysis of the reports' texts showed that out of the four types of scenarios used in the texts of the reports, only one describes the result of the research itself. With this description of extrapolation of research results from the reporting documentation to the marketing communication field becomes difficult enough.

To resolve this problem, it is proposed to extent the context of scientific discourse through classification of scientific results, as well as through the inclusion of information of marketing type. The implementation of the strategy of extending the context will increase the pragmatic constituent of the discourse: it will provide the influence to the potential consumer of system of explicit and hidden meanings, revealing scientific and market value of the scientific product derived from the research.

Key words: scientific discourse, discourse strategies, description of the scientific result, conceptualization of experience, commercialization of results, expansion of the context

\section{INTRODUCTION}

One of the philosophical backings of globalization as a process of integration and unification in science is its parameterization in terms of contextual substantiation of perception [1].

Within a particular scientific paradigm, providing a single scientific and methodological basis, the result of interdisciplinary researches becomes an extension of knowledge context. Herewith the new knowledge is generated, which acquires the feature of contextuality. Thus, contextuality of knowledge, on the one hand, is a consequence of the integrity in 
science. On the other hand, the focus on structuring the context may be defined as a strategy, the implementation of which is possible with proper selection of tools. In this statement of the question the researcher faces the need to determine the tooling of knowledge extrapolation process.

The commercialization of research results has become one of the challenges of time and marked one of the new areas of social practices. This article aims to highlight the main results of research of impact of discourse strategies in the area of final reporting of the scientific research results and their commercialization.

We have analyzed 63 discourses of description of scientific research results. They are scientific reports of the Kazakh National University Research Institute for 20102014 years. The platform of actively developing nowadays linguistic direction of discourseanalysis was elected as a scientific-theoretical and methodological basis for the research. Information technologies of SEO analysis, methods and techniques of conceptual and cognitive analysis were also used to solve the tasks of the study.

\section{THE CONCEPTUAL PART}

The problem of commercialization arose quite naturally, because the research result, as the value created in the research process, should be well described and have the perspective of implementation, including financial gains.

However, there is a challenge, but no concrete scientifically and technologically wellfounded answer how to do this yet. And paradoxically, Linguistics, studying the multidimensionality of worlds of language, can offer the development of strategy and tools of transformation of scientific discourse into a discourse with active marketing impact.

Insufficient efficiency in promoting innovative product has become one of the problems that cannot be solved within one science. A broader scientific context for interdisciplinary studies is needed. Discourse as a form of social behavior is a tool for constructing social relations and the formation of the social world and the world of science. This is possible due to the fact that the discourse creates a field of values, explicit and implicit, that define the specifics of the impact.

The idea of instrumental ability of linguistic means can be read in the works of scientists describing the modular organization of the activity of the human brain [2;3]. J. Fodor considers language as modular organized cognitive system that processes information in propositional form. Knowledge is represented in conceptual, synthesizing, comparing form, which provides saving in memory and continued use.

T. Givon identifies module of cognitive representation, presented by conceptual lexicon, propositional information and multipropositional discourse. The structure of the conceptual lexicon is traditionally presented in the form of a semantic network, in nodes of which there are separate concepts of mental representations of common cultural information, which is conventionally fixed. In fact, T. Givon leads us to understand that the conceptual component performs the function of cognitive system tool for the attribution of reality world.

Propositional information of perception, as a form of realization of knowledge, according to the scientist, is individual in its nature, and correlates with one or another 
type of presentation and can be detected or correlated as a private expression of socium experience. Once again, we see this as an opportunity to interpret propositions as a tool for understanding of relationships between subjects and objects in the world of reality.

Separate propositions, combined under the laws of thematic unity and cohesion, according to his theory, form the semantic content of multipropositional discourse, thereby ensuring its instrumental function. Discourse is already recognized as a tool providing transformation of the world through cognition and communication.

Scientific discourse as the principal instrument of the scientist refers to institutional type of discourse. The concept of institutional discourse introduced by m. Foucault, represents the type of discourse, which operates in a particular area of social being, modeling it and fully servicing. This also applies to the scientific discourse, differently serving to the research process at different levels of work performance: from the definition of aims, objectives, strategies and research methodology to description of the obtained results. It is a description of the results obtained in the research process that became the subject of our scientific interest.

Talking about the fundamentals of communion of the discourse as communicative event, M. Foucault suggests that this communion is provided by the rules, the rules of discourse data application. To the discursive data he refers the system of objects, types of expressions, concepts and thematic choice. System of concepts can vary by structure and rules of application. Concepts, forming the conceptual field of discourse, often ignore and exclude each other and may not be included in logically relevant communions. But at the same time, a variety of strategic possibilities allow to activate incompatible themes or integrate the same theme into entirely different population [4].

Exactly this picture opened in front of us, when we started researching the scientific discourse of the report: the diversity of objects of the research in the reports, the diversity of types of methodologies, the incompatibility of spheres of concepts, thematic diversity and much more. And it became clear why the scientist identifies discourse analysis as a type of analysis that does not restore the chain of findings, does not establish a table of differences, but describes a system of conditioned diffusion of discourse data.

The principle of conditionality has determined the choice of research methodology for decision of designated tasks: uncover the discursive data of researched objects (conceptual systematizations, linkage of statements, groups of objects, types of obtained results), establish relationships between them, both horizontally and vertically. In fact, there was talk of the need to establish a framework of discursive formation, which not only generates the formation of objects, but also determines the formation of strategic preferences of the discourse. Between the formations of objects and strategic preferences interdependent relations are established, which extend the context of scientific discourse. In this conditionality system, the formation of strategic preferences is the leading one, that determines the direction of broadening the context of scientific discourse.

Identifying the context of an overall problem of the research, limited by frameworks of the scientific article, we will focus only on statement of need for mandatory introduction of the formation of strategic preferences to the report discourse.

Selection of discourse analysis methodology and comprehension of discourse data of scientific reports in the system of conditionality of relationships within the discursive formations allowed us to formulate the basic thesis: discursive formations of strategic 
preferences should determine and direct the content of objects formations of the report scientific discourse. That is why it is necessary to lay two formations of strategic preferences in the discourse of the scientific report as a formation of higher order: formation of conceptualization of scientific experience and formation of marketing strategy for its commercialization.

To study the formation of objects (or conceptualizing the content) of scientific discourse of the report under subparagraph "Description of the results of scientific research", there was elected analysis of verbal concepts that make it possible to establish conditionality of relationships between objects of description, because they are representatives of event component of reporting information. In our view, it is the verb concepts allow us to activate incompatible themes and consolidate them in one picture of information, different in content, methodology of scientific reports on the various fields of natural and engineering sciences, and humanities.

Traditionally it is believed that the conceptualization of reality is most clearly presented by substantive forms of verbalization of concepts. This is due to the maximum abstracting from the situation and with maximum communicative demand of concept, verbalized with substantive. In this case, the mental essence of the concept is most visible. Verb, adverb and adjective to a lesser extent are abstract, and therefore represent a lower level of conceptualization.

However, there is also another opinion: the verb in the field structure of sphere of concept is its core component. Thus, L.G. Babenko writes: “... sphere of concept has the field structure, the core of which is a cognitive-propositional structure, which in a contracted form transmits the idea of concept. In composition of lexical-semantic groups this function is performed by basic verbs-identifiers. The concept of cognitive-propositional structure is introduced into scientific circulation due to the necessity of modeling the concept, performed with the aim of visual, demonstrative presentation of its mental structure. Such modelingbecomes possible as a result of generalization of recurrent in lexical representations of concept of its essential features, discovering knowledge about the world" [5. P. 218].

"Unlike qualitative words expressing sensual-perception signs of items, S.D. Katznelson wrote, - verb words express events with specific relationships between participating items in these events. Not quality of items, but, peculiar within the framework of this event, relationships are implied with verb words. If qualitative words are focused on each item separately and only through the subject are related to events, the verb words relate to the events directly, and by nature of events they define the set of items and substantive functions, implied by the set. It is important to stress, that verb words identify the type of this event, certain events as types" [6. P. 419].

Definition of verbs and verb words as event types allows to allocate substantial signs of their conceptualizing properties. Another confirmation of the existence of verbal concepts and importance of the place they occupy, we find in the work of V.I. Karasik "Language Keys" [7]. The author proposes seven approaches to a typology of concepts, in most of them we see verb.

The first and most revealing approach "is based on a thesis of explicit or implicit orientation of concepts to the language in which they are represented. In this case, the 
subject, indicative, and event concepts are allocated. It is clear that this typology is based on the major content words of speech in known languages" [7. P. 24].

Verb word, representing the event, can be fairly defined by event concept as some comprehension of a fragment of experience relating "with pictures, maps, scripts, frames, gestalts. In this case, one way or another, the views are structured, fixed for fragmented reality" [7. P. 24].

The most productive form of representation of event concept is a scenario - "a sequence of multiple episodes over time; these are stereotypical episodes with a sign of movement and development. In fact, those are frames, developed in space and time as a series of individual episodes, stages, elements..." [8. P. 119].

All that allows to fairly consider the verbal concept as a unit of comprehension of a fragment of experience. This understanding is carried out through the establishment of systems arising from relations between discourse data (the system of objects, types, expressions, themes), scattered in discourse. And it is verbal concept as a concept of event type that helps ensure comprehension of experience as an event in parameters of the scenario.

Institutional concepts of event type of report's scientific discourse represent a fragment of scientific experience. Owing to a temporary length of time as the lead sign of event concept, description of its content by cognitive propositional structure of a particular scenario becomes possible.

The scenario, as a means of mental representations of the verb concept as event concept, identifies the parameters of specific event via the system resulting from the relations between discourse data based on propositional structure, whose predicate is the name of the concept, presented by verb or a verb word. The main mechanism of modeling the scenario becomes a system of semantic and grammatical relations, which the verb word in the role of predicate can enter.

Technology of SEO analysis allowed to identify the semantic core of all the studied description texts of a scientific result based on frequency of use.

This core is represented by the following twenty verbs and verb words. Their frequency of use is represented by the following list:

1) explore -128 , research -305 ;

2) get -285 , receive -10 , getting -96 ;

3) develop -238 , development -136 ;

4) use -103 , to be used -28 , using -130 ;

5) hold -208 , holding -34 ;

6) define -126 , definition -48 , to be defined -15 , determine -12 ;

7) show -181 , render -18 ;

8) explore -84 , to study -6 , study -64 ;

9) to be -147 ;

10) to be formed -20 , form -7 , formation -113 ;

11) change -18 , to change -2 , change $(n)-110$;

12) establish -127 ;

13) calculate -26 , count -2 , calculation -97 ;

14) identify -116 , identification -5 ; 
15) Allow - 80, to allow - 30;

16) to be applied -6 , apply -8 , application -87 ;

17) influence (v) -7 , impact (n) -94 ;

18) interact -7 , interaction -86 ;

19) analyze -16 , analysis -71 ;

20) develop -5 , to develop -8 , development -72 .

Exactly these verb words are researched to find out if the feature of description of scientific result is performed, which, in turn, will allow to determine which of the most frequency verb words are included into the semantic core of verb sphere of concept of description of scientific result.

In the structure of lexical meaning of word the result in the dictionaries of Russian language the semes of completeness and result dominate. Therefore, from the semantic core, verbs with semes of completeness, result, productivity in the semantic structure were selected.

The first group of verbs and verb words describes the process of research - study, researched, explore; study (n), study, to study; use, to use, to be used; to hold, holding.

Analysis of verbs and verb words of the first group showed that they represent event concept in system of relationship "process - object - methodology". Mentally this typing of relations establishes a certain scenario that is modeled by propositional structure "explore what (how)". Therefore, the first event type used to describe the results of scientific research in the texts of the reports is described in the scenario "methodology and Instrumentation of research of the object".

The second group was composed of the verb units that describe the conditions of success of obtaining the final result of the research, - to define, defined, definition, to be defined; change (n), to change, change; calculation, calculate, calculated, count; identify, identified, identification; analysis, analyze, analyzed.

Concept, verbalized by verbs and verb words with semantics of "analysis", as the concept of event type, represents the type of event "an intermediate result as a condition of achieving the objective of the research", which defines the conditions for the success of obtaining the final result of the study. Event scenario is developed on the basis of propositions: what is analyzed for what purpose, by what methods, what result is obtained.

Thus, the event verb concepts used in scientific reports to describe the results of the study, are represented in the language by the system of verbs of the same nature: actional of mental actions, objectal. Semantic composition reflects the orientation on causation of object, which enables us to say that the description of the intermediate result is performed through the identification of properties, regularities, and conditions necessary for the achievement of the main objective of the research.

Verb words of the third group are involved in the product description as a result of the study - to get, receive, getting; to develop, developed, development; to show, is shown, show; formation, form, to form; establish, established.

Event verb concept represented by verb words with semantics of "getting", "development", "education", "formation", characterized by a temporary length in time, on the basis of propositions: what is received of what quality models a scenario - "getting a product of certain quality as the result of the research". 
Verbs of the fourth group are involved in describing the use of the obtained result using, use, to be used; allow, permit; application, apply, to apply, applicable; development, develop, developing, develop.

The fourth type of event is modeled on the basis of proposition where it is possible apply/use of what and represents the "recommendations on the application of the scientific product”.

\section{CONCLUSION}

The results of the research of scientific discourse of the University Research Institute reports composed and processed in accordance with GOST, showed that description of scientific result is presented by the system of four consecutive event types. The main representative of each is a scenario modeled on the basis of verb concepts. Semantic volume of verb concept is defined by the content of event represented by propositional structure of scenario. But from 4 types of scenarios, only the third type describes the result of the study itself, and the fourth contains some recommendations for use.

One of the reasons we see in the fact that in the report as discourse formation, formations of strategic preferences are absent. If the formation of the conceptualization of scientific experience is presented in volume from $1 / 4$ of the text content, then the formation of marketing strategy of commercialization of scientific results is not represented at all.

All this suggests that it is necessary to reformat the scientific discourse of describing the results of the study on the basis of calculating of discursive data, establishment of relations between them. This will allow to describe research result as a product of conceptualization of scientific experience.

The targeted expansion of context of scientific discourse by information of marketing type is required. The implementation of the strategy of extending the context will increase the pragmatic constituent of the discourse: it will provide the influence to the potential consumer of system of explicit and hidden meanings, revealing scientific and market value of the scientific product derived from the research.

Extrapolation of the research result description, as we have already pointed out, within the sphere of marketing communications with a view to its commercialization, is only possible through such a description, which in addition to scientific preferences will contain information that is capable of influencing the potential consumer of this result. All this allowed us to raise the question of the need for strategic changes in the content of the scientific report: to lay in the discourse of scientific report two formations of strategic preferences at once: on the one hand, the description of the scientific result as product of conceptualization of scientific experience, and on the other hand - alignment of marketing strategies as a tool for its commercialization.

In other words, it is necessary to expand the context of scientific report with pragmatically important information of marketing content, which should provide an impact on the potential consumer by the system of explicit and implicit meanings, revealing scientific and market value of the scientific product derived from research. Without such expansion of the context of the scientific discourse the commercialization of research results will be difficult for a long time, completely dependent on the elements of the market.

(C) Ekshembeeva L.V., Musataeva M.Sh., 2017 


\section{REFERENCES}

[1] Kornienko A.A., Ardashkin I.B., Chmykhalo A.Yu. Philosophy of science [Философия науки]. Tomsk: Ed. of TPU, 2007, p. 164.

[2] Fodor J.A. The modularity of mind. Cambridge (Mass.), 1983, p. 145.

[3] Givon T. Visual information processing system as a step in the evolution of human language [Система обработки визуальной информации как ступень в эволюции человеческого языка]. Vestnik Moskovskogo Universiteta. Ep. 9. Philology. 2004. No. 3. P. 117-145.

[4] Foucault M. Formations of Strategies [Формации стратегий]. The Archaeology of Knowledge. Transl. from French / Gen. ed. Levchenko Bros. K.: Nika-Center, 1996, p. 208.

[5] Babenko L.G. Spehere of concepts of processual-eventive world: universal, nation-wide and individual conceptual spaces [Концептосфера процессуально-событийного мира: универсальное, общенациональное и индивидуальное концептуальное пространства]. Russian word in world culture. Materials of X MAPRYAL Congress. Plenary meetings. Volume I. St. Petersburg, 2003. P. 216-220.

[6] Katsnelson S.D. Categories of language and thinking: From scientific heritage [Категории языка и мышления: Из научного наследия]. Moscow, 2001, p. 864

[7] Karasik V.I. Language keys [Языковые ключи]. Moscow: Gnosis, 2009, p. 406.

[8] Popova Z.D., Sternin I.A. Cognitive linguistics [Когнитивная лингвистика]. M.: East-West, 2007, p. 314.

\section{Article history:}

Received: 21 November 2016

Accepted: 26 December 2016

Moderator: U.M. Bakhtikireeva

\section{For citation:}

Ekshembeeva L.V., Musataeva M.Sh. (2017). Discursive strategy of scientific report and its implementation. RUDN Journal of Language Education and Translingual Practices, 14 (1), 9-17.

\section{Bio:}

Ekshembeeva Lyudmila, Doctor of Philology, Professor of Al-Farabi Kazakh National University, Almaty, Kazakhstan. E-mail: lvek@inbox.ru.

Musataeva Manat, Doctor of Philology, Professor of Abay Kazakh National Pedagogical University, Almaty, Kazakhstan. E-mail: mussatayeva@mail.ru. 


\title{
ДИСКУРСНАЯ СТРАТЕГИЯ НАУЧНОГО ОТЧЕТА И ЕЕ РЕАЛИЗАЦИЯ
}

\author{
Л.В. Екшембеева \\ Казахский национальный университет им. аль-Фараби \\ 050040, Пр-т аль-Фараби, 79, Алматы, Казахстан
}

М.Ш. Мусатаева

Казахский национальный педагогический университет им. Абая 050010, Пр-т Достык, 13, Алматы, Казахстан

Обосновывается необходимость внесения стратегических изменений в содержание научного отчета. В дискурс научного отчета следует включать сразу две формации стратегических предпочтений: описание научного результата как продукта концептуализации научного опыта; выстраивание маркетинговых стратегий как инструмента его коммерциализации.

Продемонстрирован основной инструмент концептуализации научного опыта при описании результатов исследования - система глагольных концептов событийного типа. Семантический объем глагольного концепта позволяет описать содержание события, которое репрезентируется в сознании пропозициональной структурой сценария. Результаты семантического анализа текстов отчетов показали, что из четырех типов сценариев, использованных в текстах отчетов, только один описывает собственно результат исследования. При таком описании экстраполяция результатов научных исследований из отчетной документации в сферу маркетинговой коммуникации становится весьма затруднительной.

Для решения проблемы предлагается расширение контекста научного дискурса через типологизацию научного результата, а также через включение информации маркетингового типа. Реализация стратегии расширения контекста усилит прагматическую составляющую дискурса: обеспечит воздействие на потенциального потребителя системой явных и скрытых смыслов, раскрывающих научную и рыночную ценность научного продукта, полученного в результате исследования.

Ключевые слова: научный дискурс, дискурсные стратегии, описание научного результата, концептуализация опыта, коммерциализация результата, расширение контекста

\section{История статьи:}

Поступила в редакцию: 21 ноября 2016

Принята к публикации: 26 декабря 2016

Модератор: У.М. Бахтикиреева

\section{Для цитирования:}

Екшембеева Л.В., Мусатаева М.Ш. Дискурсная стратегия научного отчета и ее реализация // Вестник Российского университета дружбы народов. Серия: Вопросы образования: языки и специальность. 2017. Т. 14. № 1. С. 9-17.

\section{Сведения об авторах:}

Екшембеева Людмила Владимировна, доктор филологических наук, профессор кафедры русской филологии и мировой литературы Казахского национального университета им. аль-Фараби, г. Алматы, Казахстан. E-mail: lvek@inbox.ru.

Мусатаева Манат Шаяхметовна, доктор филологических наук, профессор кафедры языкознания Казахского национального педагогического университета им. Абая, г. Алматы, Казахстан. E-mail: mussatayeva@mail.ru. 